\title{
ANALISA PENERAPAN PERATURAN PEMERINTAH NOMOR 60 TAHUN 2008 TENTANG SISTEM PENGENDALIAN INTERN PEMERINTAH OLEH INSPEKTORAT DI PROVINSI SULAWESI UTARA
}

\author{
Theyza Korah, Herman Karamoy, LintjeKalangi \\ korahtheyza@yahoo.co.id
}

\begin{abstract}
This research done to Analyze The Implementation Of Government Regulation Number 60 Of 2008 Concerning Internal Control Systems Of Government views from the north sulawesi 5 control elements. This is descriptive qualitative research, with developing framework to analyze think. Process and meaning. Research subjects required by using purposive sampling technique.Iepemelihan informants based researchers from consideration of certain criteria, that may be as much information from various sources. The study performed in three object of research, research and this indicates that the Government In The Province Of North Sulawesi already implement effective regulation of internal control systems and needs a good cooperation in applying such regulations as between the inspectorate of internal control and inspection unit working as object.
\end{abstract}

Keywords ; Government Regulation Number 60 Of 2008, 5 Elements Of Internal Control

\section{Pendahuluan}

\subsection{Latar belakang}

Pada era pembangunan saat ini negara kita yaitu Republik Indonesia harus mewujudkan masyarakat yang adil makmur dan sejahtera. Dan untuk mencapai hal tersebut dibutuhkan suatu sistem pemerintahan yang tidak kompromi atau tidak melegalkan setiap kepentingan yang berhubungan dengan pelanggaran norma-norma atau hukum yang berlaku yang sudah di atur dalam undang - undang sebagai dasar negara.

Beberapa daerah telah memenuhi standar tersebut sehingga meraih WTP. "Standar tersebut mengharuskan BPK-RI merencanakan dan melaksanakan pemeriksaan. Agar BPK-RI memperoleh keyakinan memadai, laporan keuangan bebas dari salah saji material. Suatu pemeriksaan meliputi penilaian atas dasar pengujian, bukti-bukti yang mendukung jumlahjumlah, dan pengungkapan dalam laporan keuangan.

Hasil pemeriksaan BPK secara keseluruhan, mengungkapkan ada 31 temuan 12 temuan merupakan kelemahan dalam desain dan penerapan sistem pengendalian intern, dan 19 temuan terkait kepatuhan per-undang-undangan, Dalam laporan BPK No. 14.A/LHP/XIX.MND/07/2014 tanggal 23 juli 2014, BPK menyatakan Opini WDP atas neraca Pemerintah Provinsi Sulut per 31 Desember 2013. Namun, Tahun 2014 Pemprov Sulut telah melakukan perbaikan atas masalahmasalah yang terjadi di Tahun Anggaran 2013 lalu. 
Tabel. 1. Opini Badan Pemeriksa Keuangan Tahun Anggaran 2011-2014

\begin{tabular}{|c|c|c|c|c|c|}
\hline No & Entitas Pemerintah Daerah & $\begin{array}{l}\text { Opini } \\
2011\end{array}$ & $\begin{array}{l}\text { Opini } \\
2012\end{array}$ & $\begin{array}{l}\text { Opini } \\
2013\end{array}$ & $\begin{array}{l}\text { Opini } \\
2014\end{array}$ \\
\hline 1 & Prov.Sulawesi Utara & WDP & WTP DPP & WDP & WTP \\
\hline 2 & Kota Manado & TW & WDP & WDP & WTP DPP \\
\hline 3 & Kab. Minahasa Utara & TMP & WDP & WDP & WDP \\
\hline 4 & Kab.Minahasa Selatan & TMP & TMP & TW & WDP \\
\hline 5 & Kab.Minahasa & WDP & TW & WDP & WTP DPP \\
\hline 6 & Kab.Minahasa Tenggara & TMP & TMP & TW & WDP \\
\hline 7 & Kab.Bolaang Mongondow & TMP & TMP & TW & WDP \\
\hline 8 & $\begin{array}{l}\text { Kab.Bolaang Mongondow } \\
\text { Selatan }\end{array}$ & TMP & WDP & WDP & WTP DPP \\
\hline 9 & $\begin{array}{l}\text { Kab.Bolaang Mongondow } \\
\text { Timur }\end{array}$ & TMP & WDP & WTP DPP & WTP DPP \\
\hline 10 & $\begin{array}{l}\text { Kab.Bolaang Mongondow } \\
\text { Utara }\end{array}$ & TMP & TMP & WDP & WDP \\
\hline 11 & Kab.Kepulauan Sangihe & WDP & WDP & WTP DPP & WTP DPP \\
\hline 12 & $\begin{array}{l}\text { Kab. Kep, Siau Tagulandang } \\
\text { Biaro }\end{array}$ & WDP & WDP & WTP DPP & WTP DPP \\
\hline 13 & Kab. Kepulauan Talaud & TMP & TW & TW & WDP \\
\hline 14 & Kota Bitung & WTP DPP & WTP DPP & WTDP DPP & WTP \\
\hline 15 & Kota Kotamobagu & TW & WDP & WTP DPP & WTP DPP \\
\hline 16 & Kota Tomohon & TMP & WDP & WTP DPP & WTP DPP \\
\hline
\end{tabular}

Sumber ; Ikhtisar Laporan Hasil Pemeriksaan BPK (www.bpk.go.id/ihps/2015/I)

Hasil pemeriksaan ini memberikan dasar yang memadai bagi BPK menyatakan pendapat atau opini. Dasar pertimbangan dalam menetapkan opini dalam LHP atas LKPD Provinsi Sulut TA 2014 yang telah diserahkan antara lain adalah opini dan tingkat planning materiality atas LKPD Provinsi Sulut TA 2014, serta berdasarkan hasil pengamatan dan evaluasi atas pengendalian intern pemerintah, dan kepatuhan terhadap peraturan per-undang-undangan. Oleh karena itu, dengan pertimbangan-pertimbangan sebagaimana di uraikan diatas BPK memberikan Opini Wajar Tanpa Pengecualian (WTP,red) atas LKPD Provinsi Sulawesi Utara tahun anggaran 2014," Berdasarkan penjelasan Pasal 16 ayat (1) Undang-undang Nomor 15 Tahun 2004 Tentang Pemeriksaan Pengelolaan dan Pertanggungjawaban Keuangan Negara, diuraikan kriteria kewajaran informasi keuangan yang disajikan dalam laporan keuangan. Kriteria tersebut mencakup kesesuaian dengan akuntansi pemerintahan, kecukupan pengungkapan (adequate disclousures), kepatuhan terhadap perundang-undangan, dan efektifitas sistem pengendalian intern ; BPKP (http://www.bpkp.go.id/sulut/berita/read/15248/0/, 23 Nopember 2015 18:29:44) Seperti yang sudah diuraikan sebelumnya, sistem pengendalian internal merupakan salah satu tahap penting dalam pendeteksian indikasi adanya penyalahgunaan kewenangan, proses sampai terlaksananya setiap program yang ada di dalam setiap Satuan Perangkat Kerja Daerah Provinsi Sulawesi Utara. Dasar pengambilan keputusan meminta pihak auditor internal untuk melakukan audit terhadap lingkungan SKPD yang ada.

Bagaimana penerapan Peraturan Pemerintah Nomor 60 tahun 2008 tentang Sistem Pengendalian Intern oleh Inspektorat di Provinsi Sulawesi Utara (Pemerintah Provinsi Sulawesi Utara, Pemerintah Kabupaten Minahasa Utara, Pemerintah Kota Manado) dilihat dari ke 5 unsur pengendalian intern, yaitu Lingkungan Pengendaliannya, Kegiatan Pengendalian, penilaian resiko, pemantauan, dan informasi/komunikasi. 
Penelitian ini bertujuan untuk menganalisis penerapan PP 60 tahun 2008 tentang Sistem Pengendalian Intern di Provinsi Sulawesi Utara (Pemerintah Provinsi Sulawesi Utara, Pemerintah Kabupaten Minahasa Utara, dan Pemerintah Kota Manado.)dilihat dari perspektif 5 unsur pengendalian, Lingkungan Pengendaliannya, Kegiatan Pengendalian, penilaian resiko, pemantauan, dan informasi/komunikasi.

\section{Tinjauan Pustaka}

\subsection{Good Corporate Governance}

Good Corporate Governance, Sebagai sebuah konsep yang memiliki definisi tunggal. Menurut komite Cadbury tahun 1992- melalui Cadbury report mengeluarkan definisi tersendiri tentang good corporate dan good governance adalah prinsip yang mengarahkan dan mengendalikan perusahaan agar mencapai keseimbangan antara kekuatan serta kewenangan perusahaan dalam memberikan pertanggungjawabannya kepada para shareholders khsusunya, dan stakeholders pada umumnya. Negara dan perangkatnya menciptakan peraturan erundang undangan yang menunjang iklim usaha yang sehat, efisien dan transaparan, melaksanakan peraturan perundang - undangan dan penegakkan huku secara konsisten (diakses tanggal 27 September 2016 jam 09:00 https://diaryintan.wordpress.com/2010/11/15/good-corporategovernance-gcg-2/).

Menurut The Indonesian Institute of Corporate Gorvernance (IIGC), Good Corporate Governance didefinisikan sebagai struktur, system, dan proses yang digunakan oleh organ organ perusahaan sebagai upaya untuk member nilai tambah perusahaan secara berkesinambungan dalam jangka panjang dengan tetap memperhatikan kepentingan stakeholders lainnya berdasrakan peraturan perundangan dan norma yang berlaku (IICG, 2009:3). Corporate Governance juga mensyaratkan adanya struktur perangkat untuk mencapai tujuan dan pengawasan atas kinerja.

2.2 Sistem Pengendalian Intern Pemerintah

Sistem Pengendalian Intern (SPI) adalah proses yang integral pada tindakan dan kegiatan yang dilakukan secara terus menerus oleh pimpinan dan seluruh pegawai untuk memberikan keyakinan memadai atas tercapainya tujuan organisasi. Tiga golongan tujuan berikut ini : keandalan pelaporan keuangan, efektifitas dan efisiensi operasi, dan kepatuhan terhadap hukum dan peraturan yang berlaku. Dalam Peraturan Pemerintah Nomor 60 Tahun 2008 tentang Sistem Pengendalian Intern Pemerintah (SPIP) dijelaskan bahwa SPIP adalah Sistem Pengendalian Intern yang diselenggarakan secara menyeluruh di lingkungan pemerintah pusat dan pemerintah daerah. Berkaitan dengan hal ini, Presiden selaku

Kepala Pemerintahan mengatur dan menyelenggarakan sistem pengendalian intern di lingkungan pemerintahan secara menyeluruh.

Terdapat 5 unsur SPIP yang perlu diimplementasikan oleh seluruh pimpinan dan staf pada semua jajaran instansi pemerintah, yaitu :

1. Lingkungan pengendalian, adalah kondisi dalam instansi pemerintah yang dapat membangun kesadaran semua personil akan pentingnya pengendalian dalam instansi untuk menjalankan kegiatan yang menjadi tanggung jawabnya sehingga dapat meningkatkan efektifitas sistem pengendalian intern.

2. Penilaian risiko adalah kegiatan penilaian atas kemungkinan kejadian yang mengancam pencapaian tujuan dan sasaran instansi pemerintah yang meliputi kegiatan identifikasi, analisis dan mengelola risiko yang relevan bagi proses atau kegiatan instansi. 
3. Kegiatan pengendalian adalah tindakan yang diperlukan untuk mengatasi risiko serta penetapan dan pelaksanaan kebijakan dan prosedur untuk memastikan bahwa tindakan mengatasi risiko telah dilaksanakan secara efektif.

4. Informasi dan komunikasi, dalam hal ini Informasi adalah data yang telah diolah yang dapat digunakan untuk mengambil keputusan dalam rangka penyelenggaraan tugas dan fungsi instansi pemerintah. Sedangkan komunikasi adalah proses penyampaian pesan atau informasi dengan menggunakan simbol atau lambang tertentu baik secara langsung maupun tidak langsung untuk mendapatkan umpan balik.

5. Pemantauan adalah proses penilaian atas mutu kinerja sistem pengendalian intern dan proses yang memberikan keyakinan bahwa temuan audit dan evaluasi lainnya segera ditindaklanjuti.

Dalam implementasinya, lingkup penyelenggaraan kelima unsur yang disebutkan di atas dapat berlaku pada tingkat instansi secara keseluruhan atau hanya berlaku pada aktivitas atau fungsi tertentu saja dalam satu instansi (pada kegiatan-kegiatan yang dilaksanakan oleh instansi). Sesuai PP Nomor 60 Tahun 2008, tiap-tiap unsur tersebut dirinci lagi kedalam sub unsur-sub unsur yang lebih detail dan bersifat teknis. Misalnya unsur pertama dirinci kedalam 8 sub unsur yang harus diterapkan, unsur kedua sebanyak 2 sub unsur, unsur ketiga terdiri dari 11 sub unsur, unsur keempat sebanyak 2 sub unsur dan unsur kelima dirinci kedalam 3 sub unsur yang harus diterapkan. Semua unsur saling terkait dan terintegrasi dam satu sistem, yaitu sistem pengendalian intern

Tahapan Penyelenggaraan SPIP di Instansi Pemerintah berkaitan dengan hal tersebut di atas, dalam mengimplementasikan SPIP di instansi pemerintah terdapat beberapa tahapan yang perlu diperhatikan pimpinan instansi dan lembaga untuk dapat mengimplementasikan SPIP secara efektif dan efisien, sebagai berikut:

Tahapan menumbuhkan kepedulian dan pemahaman 2.Tahapan Membangun desain SPIP 3.Tahapan Menjalankan dan mereview SPIP 4.Tahapan Peningkatan Keandalan Sistem 5.Karakteristik Konsep SPIP. Dalam mengembangkan SPIP pimpinan instansi pemerintah perlu memahami karakteristik konsep SPIP sehingga dalam pengembangannya dapat mewujudkan tujuan dari pengendalian tersebut terdapat karakteristik Konsep SPIP;

1. Holistik, atau integral, SPI dijabarkan dalam lima komponen utama yang saling terintegrasi, yaitu lingkungan pengendalian (control environmnent), penilaian resiko (risk assessment), aktivitas pengendalian (control activities), informasi dan komunikasi (information and communication) serta pemantauan (monitoring), dimana efektivitas penerapan sistem sangat dipengaruhi oleh komponen - komponen dapat mempengaruhi efektivitas komponen pengendaliannya.

2. Proses, sistem pengendalian interns adalah suatu proses bukan tujuan. SPI merupakan suatu proses yang apabila dijalankan dengan baik akan dapat memberikan keyakinan memadai bahwa tujuan organisasi akan dapat dicapai.

3. Tujuan organisasi sebagai pengarah (A business Objective Driven Approach), dalam membangun sistem pengendalian intern pimpinan instansi pemerintah wajib memperhatikan langkah - langkah.

4. Memiliki dua tingkatan pengendalian, yaitu pengendalian tingkat organisasi, dan pengendalian tingkat aktivitas 
5. Fleksibel, adaptif, dan tidak ada satu model dapat diterapkan untuk semua jenis organisasi. Bukan merupakan hal yang kaku. Dalam penerpannya memperhatikan ukuran, karakteristik, kompleksitas, tingkat kebutuhan, tujuan organisasi, dan cost benefitnya.

6. Memberikan keyakinan yang memadai bukan jaminan absolut (Reasonable Assurance). SPI hanya memberikan keyakinan yang memadai bukan jaminan absolut atas tercapainya tujuan pengendalian

7. Bergantung pada faktor manusia (The People Factor), efektivitas penerapan sistem pengendalian intern sangat dipengaruhi oleh orang sebagai pelaksananya yaitu jajaran pimpinan dan staf di unit organisasi tersebut. Dokumentasi penerapan pengendalian intern memang penting, namun yang lebih penting adalah efektivitas peran dari tiap - tiap pegawai.

8. Memiliki keterbatasan, efektivitas penerapan SPI pada instansi pemerintah tidak akan tercapai, apabila tidak adanya kerjasama yang baik antar pemerintah SKPD. PP Nomor 60 Tahun 2008 mewajibkan menteri/pimpinan lembaga, gubernur, dan bupati/walikota melakukan pengendalian atas penyelenggaraan kegiatan pemerintah dengan berpedoman pada SPIP sebagaimana diatur dalam PP ini, yang terdiri dari 61 pasal, 4 Bab, dan penjelasannya.Yang dimaksud dengan SPIP dalam ketentuan ini adalah sistem pengendalian intern yang diselenggarakan secara menyeluruh di lingkungan pemerintah pusat dan pemerintah daerah. Salah satu hal yang diatur dalam PP ini adalah tentang penguatan lembaga Badan Pengawasan Keuangan dan Pembangunan (BPKP). Berdasarkan PP ini, BPKP merupakan aparat pengawasan intern pemerintah yang bertanggungjawab langsung kepada Presiden. PP ini juga menyatakan bahwa tujuan ditetapkannya SPIP adalah untuk memberikan keyakinan yang memadai bagi tercapainya efektivitas dan efisiensi pencapaian tujuan penyelenggaraan pemerintahan negara

Terdapat landasan undang-undang yang mendasari pengendalian Intern:

1. Undang-Undang Nomor 28 Tahun 1999 tentang Penyelenggaraan Negara yang Bersih dan Bebas dari Korupsi, Kolusi, dan Nepotisme.

2. Undang-Undang Nomor 1 Tahun 2004 tentang Perbendaharaan Negara

3. Undang-Undang Nomor 15 Tahun 2004 tentang Pemeriksaan Pengelolaan Keuangan Negara.

4. Peraturan Pemerintah Nomor 8 Tahun 2006 tentang Laporan Keuangan dan Kinerja Instansi.

5. Peraturan Presiden Republik Indonesia Nomor 9 Tahun 2005 tentang Kedudukan, Tugas, Fungsi, Susunan Organisasi, Tata Kerja Kementrian Negara Republik Indonesia

2.2.4 Hubungan Internal Audit dan Good Corporate Governance (GCG)

Sedangkan Menurut Sutedi (2006, p.175), Corporate Governance dapat dedifinisikan sebagai "Seperangkat peraturan yang mengatur hubungan antara pemegang saham, pengurus (pengelola) perusahaan, pihak kreditur, pemerintah, karyawan serta pemegang kepentingan intern dan ekstern lainnya yang berkaitan dengan hak-hak dan kewajiban mereka atau dengan kata lain suatu sistem yang mengatur dan mengendalikan perusahaan". Suatu tata hubungan antara para stakeholders yang digunakan untuk menentukkan dan mengendalikan arah strategi dan kinerja perusahaan.Peranan internal audit dalam good corporate governance (GCG) yang dikeluarkan oleh KPMG dalam Purwaningsih (2008) berjudul Internal Audit's Role in Corporate Governance disebutkan bahwa peranan kunci internal audit adalah membantu Dewan Pengawas / Komite Audit dalam peranan internal memastikan adanya pengawasan yang memadai atas internal control dan dengan melakukan hal tersebut akan membentuk komponen yang integral dalam kerangka kerja corporate governance perusahaan. Dalam hal ini, internal audit membantu dewan pengawas dan atau komite audit dalam pemenuhan tanggung jawab atas tata kelola perusahaan yang baik. 


\subsubsection{Standar Audit Intern}

Definisi audit internal menurut IIA (Institute of Internal auditor) yang dikutip oleh Boynton (2001:980) yakni: "Internal auditing is an independent, objective assurance and consulting activity designed to add value and improve an organization's operations. It helps an organization accomplish its objectives by bringing a systematic, disciplined approach to evaluate and improve the effectiveness of risk management, control, and governance processes". (Audit internal adalah aktivitas independen, keyakinan objektif.

\section{Hipotesis dan Model \\ Kerangka Konseptual}

Kerangka penelitian yang dilakukan dalam penelitian ini menggambarkan Inspektorat di Provinsi Sulawesi Utara dalam hal ini yang menjadi sampel responden yaitu Inspektorat Pemerintah Provinsi Sulawesi Utara, Inspektorat Pemerintah Kota Manado, Inspektorat Pemerintah Kabupaten Minahaa Utara sebagai Pengendali Intern menerapakan Peraturan Pemerintah Nomor 60 tahun 2008 sebagai dasar pengendalian ke setiap (SKPD) Satuan Kerja Perangkat Daerah, yang ada.

\section{Metode Penelitian \\ 4.1 Data}

Jenis Data adalah seluruh informasi empiris dan dokumentatif yang diperoleh di lapangan sebagai pendukung kearah konstruksi ilmu secara ilmiah dan akademis. Data penelitian adalah "Known or assumed", yang berarti bahwa data itu sesuatu yang diketahui atau dianggap. Sumber data primer, sumber data yang diperoleh oleh penulis dari informan melalui wawancara kepada Kepala atau pegawai yang memiliki mengetahui sejauh mana implementasi Peraturan Pemerintah tersebut.sumber data sekunder, sumber data yang diperoleh peneliti dari Kantor Inspektorat Pemerintah Provinsi Sulawesi Utara,

4.2 Jenis Penelitian, yang dipakai adalah deskriptif kualitatif.

4.4 Lokasi dan Waktu Penelitian

Penelitian dilakukan di Inspektorat Pemerintah Provinsi Sulawesi Utara, Pemerintah Kota Manado, Pemerintah Kabupaten Minahasa Utara. Waktu Penelitian 2 Minggu

4.5 Fokus penelitian

Focus penelitian ini mengacu pada setiap pegawai atau kepala bidang yang bertanggung jawab terhadap pengimplementasian Peraturan tersebut yang diterapkan dalam prosedur ataupun program pengawasan oleh Inspektorat dalam tugasnya sebagai internal control Pemerintah Provinsi Sulawesi Utara.

4.6 Metode dan dan Teknik Analisis Data

Metode penelitian yang digunakan dalam penelitian ini menggunakan metode deskriptif dengan teknik penilitian studi kasus dan anlisis pekerjaan dan aktivitas. Dengan mengumpulkan informasi terlebih dahulu dari pegawai yang memiliki kewenangan langsung dalam pelaksanaan program pengawasan terhadap SKPD dalam hal ini auditor. Dengan melakukan wawancara kemudian melakukan analisa sejauh mana efektifitas penerapan peraturan pemerintah nomor 60 tahun 2008, dalam sistem pengawasan Inspektorat sebagai aparat pengawas internal pemerintah. Juga masalah yang dihadapi oleh Inspektorat sebagai aparat pengawas dalam menerapkan aturan tersebut, dan bagaimana inspektorat melihat dampak dari penerapan peraturan pemerintah 60 tahun 2008 terhadap pemeriksaan pada setiap SKPD. Informasi tersebut harus real dengan bentuk tekstular. Bentuk teks digunakan dalam penyajian kutipan hasil wawancara dengan para informan dalam hal ini Pegawai, (auditor) atau Kepala bidang maupun Kepala Inspektorat Data 
yang diperoleh baik yang berasal dari data primer maupun sekunder akan dianalisa dengan mengikuti konsep yang diberikan Miles, Huberman dalam Mukhtar (2013), yaitu model analisis data berlangsung atau mengalir. Menurutnya ada empat aktivitas yang dilakukan melalui pendekatan ini

1. Pengumpulan Data : merupakan proses yang berlangsung sepanjang penelitian, dengan menggunakan seperangkat instrument yang telah disiapkan, guna memperoleh informasi data melalui wawancara dan dokumentasi. Instrument utama dalam penelitian ini adalah peneliti sendiri. Dalam pengumpulan data, seorang peneliti dapat melakukan analisis secara langsung, sesuai dengan informasi di lapangan.

2. Reduksi Data : Menunjukkan proses menyeleksi, memfokuskan, menyederhanakan, mengabstraksikan dan mentransformasi data mentah yang muncul dalam penulisan catatan lapangan. Sehingga ditemukan tema atau pokok yang dianggap relevan dengan masalah dan tujuan penelitian.

3. Display Data : usaha merangkai informasi yang teroganisisr dalam upaya menggambarkan kesimpu;an dan mengambil tindakan. Biasanya bentuk display (penampilan) data kualitatif menggunakan teks narasi.

4. Verifikasi dan menarik kesimpulan : aktivitas analisis dimana, pada awal pengumpulan data, peneliti mulai memutuskan apakah sesuatu bermakna atau tidak mempunyai keteraturan, pola, penjelasan hubungan sebab akibat dan proposisi (Mukhtar, 2013)

\section{Hasil Penelitian Dan Pembahasan}

\subsection{Gambaran Umum Lokasi Penelitian}

\subsubsection{Inspektorat Provinsi Sulawesi Utara}

Inspektorat Provinsi Sulawesi Utara dibentuk berdasarkan Peraturan Daerah Provinsi Sulawesi Utara Nomor 4 Tahun 2008 tentang Organisasi dan Tata Kerja Inspektorat, Badan Perencanaan Pembangunan Daerah, Lembaga Teknis Daerah dan Lembaga Lain Provinsi Sulawesi Utara sebagaimana telah diubah dengan Peraturan Daerah Provinsi Sulawesi Utara Nomor 6 Tahun 2011 tentang Perubahan atas Peraturan Daerah Provinsi Sulawesi Utara Nomor 4 Tahun 2008 tentang Organisasi dan Tata Kerja Inspektorat, Badan Perencanaan Pembangunan Daerah, Lembaga Teknis Daerah dan Lembaga Lain Provinsi Sulawesi Utara.

Peraturan Gubernur Sulawesi Utara Nomor 63 Tahun 2008 tentang Uraian Tugas Inspektorat Provinsi Sulawesi Utara sebagaimana telah diubah dengan Peraturan Gubernur Sulawesi Utara Nomor 6 Tahun 2011 tentang Perubahan atas Peraturan Gubernur Sulawesi Utara nomor 63 tahun 2008 tentang Uraian Tugas Inspektorat Provinsi Sulawesi Utara.

Sejalan dengan dasar hukum diatas, maka Inspektorat Provinsi Sulawesi Utara memiliki ruang lingkup Tugas Pokok dan Fungsi kelembagaan sebagai berikut, Membantu Gubernur dalam melakukan pengawasan terhadap pelaksanaan urusan pemerintahan di daerah provinsi, pelaksanaan pembinaan atas penyelenggaraan pemerintahan daerah Kabupaten/Kota dan pelaksanaan urusan pemerintahan di daerah Kabupaten/Kota dan beberapa fungsi yaitu ;

1. Perencanaan program pengawasan;

2. Perumusan kebijakan dan fasilitas pengawasan;

3. Pemeriksaan, pengusutan, pengujian, dan penilaian tugas pengawasan;

4. Pemberian dukungan atas penyelenggaraan pemerintahan daerah dibidang pengawasan;

5. Penyelenggaraan urusan administrasi kesekretariatan; 
6. Pelaksanaan tugas lain yang diberikan Gubernur.

Dengan begitu terdapat Visi Inspektorat Provinsi Sulawesi Utara : Terwujudnya Pemerintahan yang Baik dan Bersih melalui Pengawasan yang Profesional dan Komprehensif. Dan Misi Misi Inspektorat Provinsi Sulawesi Utara :

1. Mendorong terciptanya penyelenggaraan pemerintahan yang bersih dan akuntabel dengan pengawasan yang profesional.

2. Menciptakan sinergitas pengawasan yang Komprehensif

\subsection{Hasil Penelitian}

Memperoleh informasi mengenai Analisa Penerapan Peraturan Pemerintah Nomor 60 Tahun 2008 Tentang Pengawasan Internal Pemerintah Oleh Inspekorat, penulis melakukan wawancara terhadap 9 orang responden, yang terbagi atas 3 objek penelitian yang dibagi atas 5 unsur pengendalian menurut Peraturan Pemerintah Nomor 60 tahun 2008, tentang Sistem Pengendalian Intern Pemerintah.

\subsubsection{Lingkungan Pengendalian}

Inspekorat Provinsi Sulawesi Utara. Menurut responden dalam pelaksanaannya Peraturan Pemerintah Nomor 60 tahun 2008 efektif berjalan di berlakukan di tuangkan dalam pemeriksaan atau pengawasan Inspektorat Provinsi pada tahun 2010 mengenai perbedaan yang mendetail dari sisi pemeriksaan keuangan dari Peraturan Pemerintah Nomor 60 tahun 2008 dengan sebelumnya tidak terlalu signifikan namun, yang menjadikannya berdampak positif dalam penerapan sebagai aturan yang disempurnakan, kalau pada tahun sebelumnya lebih melihat pada output yang dihasilkan yang disebut WASKAT atau pengawasan melekat. Namun dalam lingkungan pengendaliannya sebagai aparat pengawas sudah efektif dan dengan diberlakukannya Peraturan tersebut banyak hal yang bisa dikatakan berdampak positif seperti terarahnya pencapaian kinerja keuangan.

Dari sisi Lingkungan Pengendalian, setiap SKPD baiknya harus ada penegakan integritas dan nilai etika sekurang-kurangnya dilakukan dengan: menyusun dan menerapkan aturan perilaku; memberikan keteladanan pelaksanaan aturan perilaku pada setiap tingkat pimpinan Instansi Pemerintah; menegakkan tindakan disiplin yang tepat atas penyimpangan terhadap kebijakan dan prosedur, atau pelanggaran terhadap aturan perilaku; menjelaskan dan mempertanggungjawabkan adanya intervensi atau pengabaian pengendalian intern, kepemimpinan yang kondusif Pembentukan struktur organisasi yang sesuai dengan kebutuhan, pendelegasian wewenang dan tanggung jawab yang tepat; penyusunan dan penerapan kebijakan yang sehat tentang pembinaan sumber daya manusia; perwujudan peran aparat pengawasan intern pemerintah yang efektif; dan hubungan kerja yang baik dengan Instansi Pemerintah terkait.

\subsubsection{Kegiatan Pengendalian}

Inspektorat Provinsi Sulawesi Utara.Tantangan dalam melakukan kegiatan pengendalian khususnya dalam melakukan audit pada setiap SKPD atau unit kerja. Kepala SKPD belum memahami yang menjadi tugas mereka untuk mengembangkan sistem pengendalian intern mereka sendiri, dan keterbukaan SKPD kurang sehingga pada saat pemeriksa eksternal dalam hal ini BADAN PEMERIKSA KEUANGAN melakukan audit maka banyak terjadi kesalahan yang mengakibatkan temuan yang berpotensi untuk kerugian.

Dalam proses kegiatan pengendalian sebelum dilaksanakan pengawasan pihak pemerintah kabupaten Minahasa Utara khususnya Pihak Inspektorat bersama dengan Pihak Badan Keuangan Daerah selalu melakukan sosialisasi maupun seminar untuk meningkatkan dan 
memperkuat dasar dalam pengelolaan keuangan agar pada proses berjalannya tidak memiliki kesalahan atau hal-hal yang tidak diinginkan. Maka selanjutnya pihak Inspektorat sebagai pengendali intern melakukan kegiatan pengendalian untuk membenahi setiap kekurangan pada proses berjalannya tahun anggaran.

\subsubsection{Penilaian Resiko}

Dalam hal penilaian resiko sesuai dengan unsur pengendalian internal dalam pp 60 tahun 2008 adakah pembobotan atau penilaian pemberian skala terhadap temuan yang ada, atau ada perlakuan khusus terhadap akun tertentu menurut resiko fraud maupun akibat yang kemungkinan terjadi?

Inspektorat sebagai pengawas internal memiliki penilaian resiko terhadap objek pemeriksaan dengan masing - masing SKPD atau unit kerja yang ada. Maka dilakukan perencanaan pengawasan dari setiap tim pengawas terhadap masing - masing objek pengawasan yang memiliki latar pekerjaan yang beragam yang signifikan yaitu SKPD yang memiliki pendapatan lebih besar dari pengeluaran, juga sebaliknya SKPD yang pengeluarannya lebih besar dari pendapatan contohnya peningkatan infrastruktur dan penerimaan pendapatan daerah. Sedangkan untuk skala pembobotan tidak ada.

\subsubsection{Monitoring dan Pemantauan}

Monitoring dan pemantauan dilakukan Inspektorat biasanya dilakukan sebelum penyusunan anggaran biasanya monitoring dilakukan untuk mereview rencana kerja anggaran sebelum disahkan maka Inspektorat dalam hal ini sebagai pengawas, melakukan review atau bahas bersama rencana kerja anggaran yang akan di sahkan sesuai dengan peraturan perundangan dan kebijakan yang berlaku. Monitoring biasanya dilakukan pada per SKPD dan dibahas bersama sebelum anggaran di input ke BPKBMD dan selanjutnya disetujui oleh Dewan Perwakilan Rakyat.

Reviu atas kinerja Instansi Pemerintah dilaksanakan dengan dengan monitoring dan membandingkan kinerja dengan tolok ukur kinerja yang ditetapkan. Juga pengelolaan sistem informasi dilakukan untuk memastikan akurasi dan kelengkapan informasi. Pengelolaan sistem informasi meliputi, pengendalian umum mengenai aturan dan kepegawaian, dan pengendalian aplikasi. Pengendalian umum terdiri atas: pengamanan sistem informasi; pengendalian atas akses; pengendalian atas pengembangan dan perubahan perangkat lunak aplikasi. Hal ini yang menjadi monitoring terhadap SKPD yang ada.

\subsubsection{Informasi dan komunikasi}

Dalam setiap pembahasan, maupun monitoring yang dilakukan semuanya tidak terlepas dari data berupa informasi dan untuk terciptanya lingkungan pengendalian yang sehat dan kondusif dibutuhkan komunikasi yang baik. Maka setiap pengendali intern informasi dan komunikasi adalah hal yang penting. Contohnya informasi tentang asset SKPD, maupun informasi sisa persediaan itu merupakan hal yang baru pada saat standard pelaporan saat ini yang berbasis akrual maka komunikasi dan informasi sangat diperlukan secara intensif untuk terciptanya suatu informasi laporan keuangan yang handal dan dapat dipercaya.

\subsection{Pembahasan Penelitian}

\section{Lingkungan Pengendalian}

Inspektorat sebagai rekan kerja setiap SKPD yang ada menjadi suatu teladan dalam melaksanakan aturan pemerintah yang yang berlaku selain sebagai satuan kerja yang melaksanakan aturan yang berlaku menegakan nilai etika dan integritas sebagai aparat pengawas, juga memiliki komitmen terhadap kompetensi mereka masing - masing sebagai, Inspektur, 
sampai pada jabatan fungsional sebagai auditor. Guna pendelegasian wewenang yang sesuai dengan kebutuhan dari pemerintahan maka dalam waktu berjalan ini Pemerintah Provinsi Sulawesi Utara akan ada penambahan tenaga audior dengan jumlah 20 orang, untuk membantu efektifnya pengawasan yang ada kesetiap SKPD. Pembentukan struktur yang disesuaikan dengan kebutuhan dan ketersediaan sumber daya yang ada khususnya untuk menempati jabatan struktural yang tugasnya mengkoordinir setiap unit staf yang ada.

Dalam menjamin keamanan atau adanya aset pemerintah daerah yang ada sesuai dengan pasal 11 dalam Peraturan Pemerintah Nomor 60 tahun 2008, poin a; memberikan keyakinan yang memadai atas ketaaatan, kehematan, efisiensi, dan efektifitas pencapaian tujuan penyelenggaraan tugas dan fungsi Instansi Pemerintah maka setiap Pemerintah Daerah Provinsi, Kabupaten maupun kota harus menjamin ketersediaan, keamanan aset yang ada.

\section{Penilaian Risiko}

Pengendalian intern harus memberikan penilaian atas risiko yang dihadapi unit organisasi baik dari luar maupun dari dalam. Dalam hal penilaian risiko Inspektorat sebagai aparat pengawas beberapa hal yang dilihat menjadi resiko atas pengendalian, seperti pada saat ini pada sistem pencatatan keuangan sudah komputerisasi. Dalam menjalankan sistem yang dilihat dilapangan pengelola sistem yang ada, yaitu sumber daya manusia dalam hal ini bukan Aparat Sipil Negara tetapi yang menjadi pengelola sistem keuangan yaitu tenaga harian atau tenaga kontrak. Pada dasarnya lingkungan pengendalian atas tenaga kontrak tidak memiliki dasar hukum yang mutlak dalam melaksanakan tugas tersebut. Karena apabila terjadi kesalahan terhadap sistem tersebut, maka yang bertanggung jawab yaitu pihak Aparat Sipil Negara.

\section{Kegiatan Pengendalian}

Kegiatan pengendalian membantu memastikan bahwa arahan pimpinan Instansi Pemerintahan dilaksanakan. Kegiatan pengendalian harus efisien dan efektif. Kegiatan pengendalian dilakukan oleh Inspetkorat sebagai aparat pengawas internal pemerintah dalam rangka untuk meminimalisasi resiko yang mengakibatkan terjadinya kerugian terhadap aset maupun tidak efisiennya pemakaian anggaran.

Sebelumnya dilakukan pengawasan melekat yang sering di sebut WASKAT. Pengawasan Atasan Langsung yang lebih familier disebut Pengawasan Melekat memiliki dasar yaitu : Instruksi Presiden Nomor 15 Tahun 1983 tentang Pedoman Pelaksanaan Pengawasan Presiden Republik Indonesia sebelum Peraturan Pemerintah Nomor 60 tahun 2008 diterapkan.

Penyelenggaraan kegiatan pengendalian dibagi pada kegiatan pokok instansi Pemerintah, harus dikaitkan dengan proses penilaian resiko, kebijakan dan prosesdur harus diterapkan secara tertulis. Kegiatan pengendalian yang dilaksanakan oleh Inspektorat Pemerintah Provinsi, maupun Kabupaten Kota meliputi;

1. reviu atas kinerja Instansi Pemerintah yang bersangkutan

2. pengendalian atas fisik atas aset dan keuangan

3. otorisasi atas transaksi dan kejadian yang penting

4. dokumentasi yang baik atas sistem pengendalian intern serta transaksi dan kejadian.

Setiap kegiatan pengendalian tersebut penting. Namun dari ketiga objek penelitian yaitu; Inspektorat Pemerintah Provinsi Sulawesi Utara, Inspektorat Pemerintah Kota Manado, dan Inspektorat Pemerintah Kabupaten Minahasa Utara. Menurut informasi yang saya peroleh yang menjadi prioritas objek pemeriksaan dari pengawas internal yaitu keuangan dan aset. 
Permasalahan efisiensi yang menjadi titik penghematan anggaran. Yang adalah juga masalah ketepatan sasaran anggaran, sesuai dengan kebutuhan. Oleh Aparat Pengawas Internal Pemerintah Provinsi Sulawesi Utara, telah menerapkan efisiensi anggaran melalui setiap kegiatan yang dilakukan oleh intern Pemerintah di lingkungan SKPD di selenggarkan di gedung milik pemerintah daerah tidak menyelenggarakan di fasilitas seperti perhotelan dan sebagainya. Sebagai pengawas hal itu ditegaskan guna efisiensi keuangan anggaran. Seperti yang tertera dalam Peraturan Pemerintah Nomor 60 tahun 2008 Bagian I Lingkungan Pengendalian poin G, Di dalam Instansi Pemerintah, terdapat mekanisme untuk memberikan keyakinan yang memadai atas ketaatan, kehematan, efisiensi, dan efektifitas pencapaian tujuan penyelenggaraan tugas dan fungsi instansi Pemerintahan.

\section{Informasi dan Komunikasi}

Informasi harus dicatat dan dilaporkan kepada pimpinan Instansi Pemerintah dan pihak lain yang ditentukan. Informasi disajikan dalam suatu bentuk dan sarana melaksanakan pengendalian dan tanggung jawabnya. Sistem informasi untuk mengidentifikasi dan mencatat informasi operasional dan keuangan yang penting yang berhubungan dengan peristiwa internal dan eksternal telah ada dan diimplementasikan. Informasi tersebut dikomunikasikan kepada pimpinan dan pihak lain di lingkungan Instansi Pemerintah dalam bentuk yang memungkinkan pihak tersebut melaksanakan tugas dan tanggung jawabnya secara efisien dan efektif. Pimpinan Instansi Pemerintah memastikan bahwa komunikasi internal telah terjalin dengan efektif.

Informasi lainnya oleh pihak Pengawas yang dilakukan pada tahap perencanaan maka pengawasan yang dilakukan berdasarkan Peraturan Pemerintah Nomor 58 tahun 2005 tentang Pengelolaan Keuangan Daerah dalam Bab IV Penyusunan Rancangan APBD Pasal 29 sampai dengan pasal 42 dijelaskan bahwa proses penyusunan RAPBD berpedoman pada Rencana Pembangunan Jangka Menengah Daerah (RPJMD), Rencana Kerja Pemerintah Daerah (RKPD), Kebijakan Umum APBD, Prioritas dan Plafon Anggaran Sementara (PPAS) dan Rencana Kerja Anggaran SKPD (RKA-SKPD).

APBD mempunyai fungsi :

1. Fungsi Otorisasi mengandung arti bahwa anggaran daerah menjadi dasar untuk melaksanakan pendapatan dan belanja pada tahun yang bersangkutan;

2. Fungsi Perencanaan mengandung arti bahwa anggaran daerah menjadi pedoman bagi manajemen dalam merencanakan kegiatan pada tahun yang bersangkutan;

3. Fungsi Pengawasan mengandung arti bahwa anggaran daerah menjadi pedoman untuk menilai apakah kegiatan penyelenggaraan pemerintahan daerah sesuai dengan ketentuan yang telah ditetapkan;

4. Fungsi Alokasi mengandung arti bahwa anggaran daerah harus diarahkan untuk menciptakan lapangan kerja/ mengurangi pengangguran dan pemborosan sumber daya, serta meningkatkan efisiensi dan efektifitas perekonomian;

5. Fungsi Distribusi mengandung arti bahwa kebijakan anggaran daerah harus memperhatikan rasa keadilan dan kepatutan;

6. Fungsi stabilisasi mengandung arti bahwa anggaran pemerintah daerah menjadi alat untuk memelihara dan mengupayakan keseimbangan fundamental perekonomian daerah.

Sebelum berlakunya sistem Anggaran Berbasis Kinerja, APBD disusun dengan menggunakan metoda tradisional atau item line budget. Mekanisme penyusunan anggaran ini tidak didasarkan pada analisa rangkaian kegiatan yang harus dihubungkan dengan tujuan yang telah ditentukan, namun lebih meniitikberatkan pada kebutuhan untuk belanja / pengeluaran. 


\section{Monitoring dan Pemantauan}

Pemantauan atau monitoring sering dilakukan sebagai Aparat Pengawas Internal kepada setiap SKPD atau unit kerja. Monitoring setelah waktu pemeriksaan dilakukan pihak Inspektorat untuk memberi waktu apabila ada kesalahan maupun kekeliruan sengaja maupun tidak sengaja yang pada dasarnya sudah tidak sesuai sesuai dengan standard atau peraturan yang berlaku maka, pihak Inspektorat memberikan kesempatan untuk memeperbaiki sebelum pemeriksa eksternal atau dalam hal ini Badan Pemeriksa Keuangan mengaudit unit kerja yang ada. Hal ini dilakukan untuk menghindari hal - hal yang merugikan Instansi Pemerintahan maupun Pemerintah Daerah yang ada.

\section{Kesimpulan, Keterbatasan dan Saran}

\subsection{Kesimpulan}

\section{Lingkungan Pengendalian}

Dampak Penerapan Peraturan Pemerintah Nomor 60 tahun 2008 Dilihat dari ke 5 Unsur Pengendalian Intern oleh Inspektorat Provinsi Sulawesi Utara, Kota Manado, Kabupaten Minahasa Utara. Dari sisi Lingkungan Pengendalian oleh Pemerintah Provinsi Sulawesi Utara penerapan peraturan pemerintah nomor 60 tahun 2008 pada setiap daerah khsususnya oleh Inspektorat Pemerintah Provinsi Sulawesi Utara, setiap pengendalian internal yang dilakukan sudah di laksanakan dengan baik dengan kerjasama antara pihak Inspektorat bersama SKPD ataupun unit kerja yang ada.

\section{Kegiatan Pengendalian}

Selain kerjasama antara pihak Inspektorat Provinsi Sulawesi Utara bersama SKPD, juga kepala SKPD sebagai pengendali internal sendiri pada unit kerjanya. Khusus untuk lingkungan pengendalian pemerintah provinsi terus memelihara keselarasan kerja, sehingga sistem pengendalian intern yang sehat, dan positif terus berkembang dan dipertahankan.

\section{Informasi dan Komunikasi.}

Inspektorat melalui unsur pengendalian informasi dan komunikasi pihak Inspekortat Provinsi Sulawesi Utara, sudah menerapkan dalam pengawasan agar setiap SKPD atau unit kerja, untuk informasi dokumentasi atas aset fisik dan keuangan itu dilakukan secara real dan dapat dipertanggunjawabkan. Dan apabila didapati adanya kekurangan informasi atas laporan atas aset dan keuangan pihak Inspektorat sebagai pengawas selalu mengkomunikasikan antar unit kerja dengan baik, agar sebaiknya di revisi sesuai dengan data real agar pertanggungjawaban laporan keuangan relevan dan dapat dipercaya.

\section{Pemantauan}

Inspektorat Provinsi Sulawesi Utara unsur Pengendalian pemantauan Inspektorat Provinsi Sulawesi Utara dalam melakukan pemantauan, setelah dilakukan audit maka diberikan kesempatan unit kerja atau SKPD yang ada untuk mereview hasil audit yang ada, seperti kurangnya dokumen yang diberikan data hutang yang belum real atau lengkap dan juga pemantauan dilakukan sejak penyusunan rencana kerja anggaran tahun anggaran 2016. Pemantauan harus dapat menilai kualitas kinerja dari waktu ke waktu dan memastikan bahwa rekomendasi hasil audit dan reviu lainnya dapat segera ditindaklanjuti pemantauan kukan review atas pengendalian piutang yang real dengan piutang yang dilaporkan oleh unit kerja atau SKPD maka Inspektorat sebagai pengawas internal mendata dan meneliti unit kerja 
yang berpotensi memiliki piutang dan mereview atas pengakuan atas piutang tersebut agar informasi yang di dapati adalah informasi yang jelas dan bisa dipertanggungjawabkan

\subsection{Keterbatasan Penelitian}

1. Dalam pelaksanaan penelitian responden yang ada memiliki keterbatasan waktu, karena pada saat penelitian responden rata-rata sedang dalam tugas pemeriksaan ke unit SKPD sehingga waktu wawancara terbaatas sehingga jawaban dari pertanyaan yang dirancang sebagian dipilih mana yang bias dijawab.

2. Jumlah responden yang direncanakan peniliti 5 orang tapi pada saat wawancara jumlah auditor yang ada dan diberikan kesempatan oleh Inspektur seperti di Pemerintah Provinsi Sulawesi Utara dan Pemerintah Kota Manado yang ditugaskan oleh Inspektur atau kasubag bagian evaluasi dan pelaporan menrurut peneliti adalah auditor yang memiliki memiliki waktu untuk diadakan wawancara dan juga auditor yang diketahui bahwa bisa memberikan informasi yang baik dan sesuai dengan materi peneliti.

\subsection{Saran}

Berdasarkan pengalaman yang ada agar terciptanya Lingkungan Pengendalian yang efektif sesuai dengan Peraturan Pemerintah Nomor 60 tahun 2008 diharapkan setiap pemerintah daerah membutuhkan kerjasama yang baik antara pihak Inspektorat sebagai pengendali intern dan setiap pihak SKPD atau unit kerja, meliputi unsur lingkungan pengendalian, penilaian resiko, kegiatan pengendalian, informasi dan komunikasi dan pemantauan yang baik agar dalam penilaian terhadap laporan keuangan mendapat opini Wajar Tanpa Pengecualian. Sesuai Peraturan Pemerintah Nomor 13 mekanisme yang ada sesuai dengan SOP berjalannya administrasi yang ada. Untuk menjunjung akuntabilitas dan transparansi Laporan keuangan.

\section{DAFTAR PUSTAKA}

A.Alimul Hidayat. 2007. Metode Penelitian Kebidanan Dan Tehnik Analisis Data. Surabaya: Salemba empat

Badan Pemeriksa Keuangan, Peraturan BPK RI No. 01 tahun 2007 tentang Standar Pemeriksaan Keuangan Negara

Boynton , Wiliam C., Johnson, Raymond N., and kell, Walter G. (2002). Modern Auditing. Edisi ke 7 Jilid 1. Jakarta ; Penerbit Erlangga

Committee of Sponsoring Organizationsof the Treadway Commissions (COSO). (1992). Internal Control - Intergrated Framework. [Online]. Tersedia: http://www.coso.org. [12 Agustus 2010].

IGC The Indonesian Institute of Corporate Gorvernance (http://www.bpkp.go.id/index, jam 14:46, tgl 8 Februari 2007) [Online] (http://xerma.blogspot.co.id/2014/04/pengertiangood-corporate-governance.html, jam 19:39, tgl 12 April 2016)

Harahap, S. 2008. Penerapan Economic Order Quantity (EOQ) UGM : Yogyakarta

Hudri Chandry (2009:10), Tanggung Jawab Auditor, online (http://yannachmad.blogspot.co.id/2012/04/auditor.html, 19:30, 26 Maret 2016)

Indonesian Institute for Corporate Governance (IICG). 2010. Good Corporate Governance Sebagai Budaya. Jakarta

Ikatan Akuntansi Indonesia, Standar Profesional Akuntan Publik (SPAP) (2001:322.1) online (http://yann-achmad.blogspot.co.id/2012/04/auditor.html, 19:34, 26 Maret 2016) 
Miller, critied by kell and Boynton Kerangka lengkap standard audit intern, 1992 :810) dalam nasution 2008

Peraturan Pemerintah Nomor 60 tahun 2008 Tentang Sistem Pengendalian Intern, online (http://www.bpkp.go.id/polsoskam/konten/501/Download-PP-60.bpkp, 21:09, 21 Maret 2016)

Sawyer et, Dittnhofer, Scheiner. (2005). Sawyer's Internal Auditing. Edisi 5. Salemba Empat, Jakarta

Courtemanche, Gil. 2006. The New Internal Auditing. Cetakan kesembilan (Penerjemah : Hiro Tugiman, Yogyakarta)

Pedoman Pemeriksaan Akuntansi, Penerbit PPA - STAN, Jakarta, 2000

Sutedi, Adrian. 2011. Good Corporate Governance. Sinar Grafika. Jakarta.

Widiyanto, B. 2010. Populasi Dan Sampel Penelitian. Jakarta: Pusat Perbukuan Kementrian Pendidikan Nasional. 